\title{
HIP1/PDGFRB Fusion Protein
}

National Cancer Institute

\section{Source}

National Cancer Institute. HIP1/PD GFRB Fusion Protein. NCI Thesaurus. Code C99504.

A fusion protein encoded by the HIP1/PDGFRB fusion gene. This protein is comprised of the first 950 amino acids of Huntingtin-interacting protein 1 fused to the C-terminal transmembrane and cytoplasmic domains of the beta-type platelet-derived growth factor receptor protein, including the protein kinase domain. 